\title{
Characterization and protective effects of lytic bacteriophage pAh6.2TG against a pathogenic multidrug-resistant Aeromonas hydrophila in Nile tilapia (Oreochromis niloticus )
}

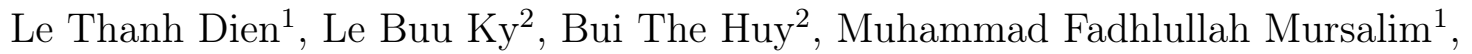 \\ Pattanapon Kayansamruaj ${ }^{3}$, Saengchan Senapin ${ }^{4}$, Channarong Rodkhum ${ }^{1}$, and Ha Dong ${ }^{5}$ \\ ${ }^{1}$ Chulalongkorn University Faculty of Veterinary Science \\ ${ }^{2}$ Truong Dai hoc Tien Giang \\ ${ }^{3}$ Kasetsart University Faculty of Fisheries \\ ${ }^{4}$ National Center for Genetic Engineering and Biotechnology \\ ${ }^{5}$ Suan Sunandha Rajabhat University Faculty of Science and Technology
}

June 14, 2021

\begin{abstract}
Bacteriophage is considered an alternative to antibiotics and environmentally friendly approach to tackle antimicrobial resistance (AMR) in aquaculture. Here, we reported isolation, morphology and genomic characterizations of a newly isolated lytic bacteriophage, designated pAh6.2TG. Host range and stability of pAh6.2TG in different environmental conditions, and protective efficacy against a pathogenic multidrug-resistant (MDR) Aeromonas hydrophila in Nile tilapia were subsequently evaluated. The results showed that pAh6.2TG is a member of the family Myoviridae which has genome size of 51,780 bp, encoding 65 putative open reading frames (ORFs), and is most closely related to Aeromonas phage PVN02 (99.33\% nucleotide identity). The pAh6.2TG was highly specific to A. hydrophila and infected $83.3 \%$ tested strains of MDR A. hydrophila (10 out of 12) with relative stability at $\mathrm{pH} 79$, temperature $040{ }^{\circ} \mathrm{C}$ and salinity $040 \mathrm{ppt}$. In experimental challenge, pAh6.2TG treatments significantly improved survivability of Nile tilapia exposed to a lethal dose of the pathogenic MDR A. hydrophila, with relative percent survival (RPS) of $73.3 \%$ and $50 \%$ for phage multiplicity of infection (MOI) 1.0 and 0.1, respectively. Significant reduction of bacterial counts in rearing water at $3 \mathrm{~h}(6.7 \pm 0.5$ to $18.1 \pm 6.98$ folds $)$ and in fish liver at $48 \mathrm{~h}$ post-treatment $(2.7 \pm$ 0.24 to $34.08 \pm 26.4$ folds) was observed in phage treatment groups while opposite pattern for bacterial counts was observed in untreated control. Interestingly, the surviving fish provoked specific antibody (IgM) against the challenged A. hydrophila. These results might explain the higher survival in phage treatment groups. In summary, the findings suggested that the lytic bacteriophage pAh6.2TG is an effective alternative to antibiotics to control MDR A. hydrophila in tilapia and possibly other freshwater fish.
\end{abstract}

\section{Characterization and protective effects of lytic bacteriophage pAh6.2TG against a pathogenic multidrug-resistant Aeromonas hydrophila in Nile tilapia (Oreochromis niloticus)}

Le Thanh Dien ${ }^{1,2,3}$, Le Buu Ky ${ }^{3}$, Bui The $\mathrm{Huy}^{3}$, Muhammad Fadhlullah Mursalim ${ }^{1,2,4}$, Pattanapon Kayansamruaj $^{5,6}$, Saengchan Senapin ${ }^{7,8}$, Channarong Rodkhum ${ }^{1^{*}}$, Ha Thanh Dong ${ }^{9,10^{*}}$

${ }^{1}$ Fish Infectious Diseases Research Unit (FID RU), Department of Veterinary Microbiology, Faculty of Veterinary Science, Chulalongkorn University, Bangkok, Thailand

${ }^{2}$ The International Graduate Program of Veterinary Science and Technology (VST), Faculty of Veterinary Science, Chulalongkorn University, Bangkok, Thailand 
${ }^{3}$ Department of Biotechnology and Plant Protection, Faculty of Agriculture and Food Technology, Tien Giang University, Tien Giang, Vietnam

${ }^{4}$ Veterinary Study Program, Faculty of Medicine, Hasanuddin University, Makassar, Indonesia

${ }^{5}$ Center of Excellence in Aquatic Animal Health Management, Faculty of Fisheries, Kasetsart University, Bangkok, Thailand

${ }^{6}$ Department of Aquaculture, Faculty of Fisheries, Kasetsart University, Bangkok, Thailand

${ }^{7}$ National Center for Genetic Engineering and Biotechnology (BIOTEC), National Science and Technology Development Agency (NSTDA), Pathum Thani, Thailand

${ }^{8}$ Fish Health Platform, Center of Excellence for Shrimp Molecular Biology and Biotechnology (Centex Shrimp), Faculty of Science, Mahidol University, Bangkok, Thailand

${ }^{9}$ Faculty of Science and Technology, Suan Sunandha Rajabhat University, Bangkok, Thailand

${ }^{10}$ School of Environment, Resources and Development, Asian Institute of Technology, Pathum Thani, Thailand

Running head : Lytic phage against MDR Aeromonas hydrophila

Corresponding authors:

H. T. Dong (hadongntu@gmail.com)

C. Rodkhum (channarong.r@chula.ac.th)

\section{Highlights}

- A lytic phage pAh6.2TG specific to multidrug-resistant (MDR)Aeromonas hydrophila isolates was isolated, identified and characterized in this study.

- pAh6.2TG was classified as a member of the family Myoviridaewhich has genome size of 51,780 bp, encoding 65 putative open reading frames (ORFs)

- pAh6.2TG was highly stable at $\mathrm{pH}=79$, temperature from 4 to $40^{\circ} \mathrm{C}$, and salinity from 0 to 40 ppt.

- Phage pAh6.2TG significantly improved survivability of Nile tilapia challenged with the pathogenic MDR A. hydrophila with RPS of $5073.3 \%$

\section{Abstract}

Bacteriophage is considered an alternative to antibiotics and environmentally friendly approach to tackle antimicrobial resistance (AMR) in aquaculture. Here, we reported isolation, morphology and genomic characterizations of a newly isolated lytic bacteriophage, designated pAh6.2TG. Host range and stability of pAh6.2TG in different environmental conditions, and protective efficacy against a pathogenic multidrugresistant (MDR) Aeromonas hydrophila in Nile tilapia were subsequently evaluated. The results showed that pAh6.2TG is a member of the family Myoviridae which has genome size of 51,780 bp, encoding 65 putative open reading frames (ORFs), and is most closely related to Aeromonas phage PVN02 (99.33\% nucleotide identity). The pAh6.2TG was highly specific to A. hydrophila and infected $83.3 \%$ tested strains of MDR A. hydrophila (10 out of 12) with relative stability at $\mathrm{pH} 79$, temperature $040{ }^{\circ} \mathrm{C}$ and salinity 040 ppt. In experimental challenge, pAh6.2TG treatments significantly improved survivability of Nile tilapia exposed to a lethal dose of the pathogenic MDR A. hydrophila, with relative percent survival (RPS) of $73.3 \%$ and $50 \%$ for phage multiplicity of infection (MOI) 1.0 and 0.1, respectively. Significant reduction of bacterial counts in rearing water at $3 \mathrm{~h}(6.7 \pm 0.5$ to $18.1 \pm 6.98$ folds $)$ and in fish liver at $48 \mathrm{~h}$ post-treatment $(2.7$ \pm 0.24 to $34.08 \pm 26.4$ folds) was observed in phage treatment groups while opposite pattern for bacterial counts was observed in untreated control. Interestingly, the surviving fish provoked specific antibody (IgM) against the challenged $A$. hydrophila. These results might explain the higher survival in phage treatment groups. In summary, the findings suggested that the lytic bacteriophage pAh6.2TG is an effective alternative to antibiotics to control MDR A. hydrophila in tilapia and possibly other freshwater fish. 
Keywords: Aeromonas hydrophila, alternative to antibiotics, antimicrobial resistance, aquaculture, bacteriophage, multidrug resistance

\section{INTRODUCTION}

The farming of carps, tilapias, and catfishes accounts for $35.84 \%$ of world aquaculture production with revenue of 83 billion dollars in 2018. They contribute not only great economic value but also food and global nutrition security (FAO, 2020; Naylor et al., 2021). One of the challenges for sustainable aquaculture is production loss due to infectious diseases (Stentiford et al., 2020; Stentiford et al., 2017).Aeromonas hydrophila infection is considered one of the most important bacterial diseases responsible for the loss of millions of dollars in the global freshwater aquaculture industry (da Silva et al., 2012; Hossain et al., 2014; Peterman \& Posadas, 2019; Pridgeon \& Klesius, 2012). The control of this disease still heavily relies on antibiotics, especially in lowmiddle income countries (LMICs). Consequently, a global issue of concern of multidrug-resistant (MDR) $A$. hydrophila is becoming increasingly ubiquitous (Guz \& Kozinska, 2004; Patil et al., 2016; Stratev \& Odeyemi, 2016). Non-antibiotic approaches can minimize the requirement for antimicrobials to tackle infectious diseases in both animals and human health (Hoelzer et al., 2018). In the battle to combat A. hydrophila infection in aquaculture system, bacteriophage is one of the environmentally friendly approaches which replace or complement chemotherapy to reduce the hazard of bacterial disease and antimicrobial resistance in aquatic animals.

Lytic bacteriophages (also called phages) are unique viruses that can infect and kill bacterial cells (Kutateladze \& Adamia, 2010). Phage therapy is a viable option to control bacterial infections due to their unique advantages, including high host specificity, rapid self-proliferation, and low intrinsic toxicity (Cao et al., 2021). For instance, Luo et al. (2018) injected phage HN48 with multiplicity of infection (MOI) $=1$ (MOI represents the ratio of the numbers of virus particles to the numbers of the host cells) against Streptococcus agalactiae infection in Nile tilapia (Oreochromis niloticus ) with relative percent survival (RPS) of $60 \%$. Feeding phage cocktails of PVHp5 and PVHp8 showed protective effectiveness in turbot (Scophthalmus maximus ) against Vibrio harveyi infection with RPS from 38.6 to $79.5 \%$ (Cui et al., 2021). In addition, intraperitoneal injection of phages FpV4 and FPSV-D22 showed protection of rainbow trout (Oncorhynchus mykiss ) to Flavobacterium psychrophilum with RPS of $53.8 \%$, while feed-based and bath administrations were not effective (Donati et al., 2021). Previous studies have demonstrated that phages can be applied in aquaculture to combat $A$. hydrophila infection (Anand et al., 2016; Cao et al., 2020; Dang et al., 2021; Jun et al., 2013; Le et al., 2018). Hence, strategy using phages for biocontrol of A. hydrophila has become increasingly attractive. The earlier studies have analyzed phenotypic and genotypic characterization, and evaluated protective effect of phages against A. hydrophila, including Myoviridae pAh1-C and pAh6-C (Jun et al., 2013); Podoviridae Ahp1 (Wang et al., 2016); Myoviridae pAh-1 (Easwaran et al., 2017); Myoviridae CT45P and TG25P (Hoang et al., 2019); Podoviridae MJG (Cao et al., 2020), Myoviridae AHP-1 (Chandrarathna et al., 2020); Siphoviridae Akh-2 (Akmal et al., 2020), Podoviridae LAh1-LAh6, Siphoviridae LAh7, and Myoviridae LAh10 (Kabwe et al., 2020); Myoviridae PVN-02 (Tu et al., 2020); Myoviridae AhyVDH1 (Cheng et al., 2021). In this study, we isolated and characterized specific an A. hydrophila phage from water sources in Mekong Delta, Vietnam. Subsequently, we evaluated its protective effects for juvenile Nile tilapia challenged with a pathogenic MDR A. hydrophila .

\section{MATERIALS AND METHODS}

\section{Bacterial isolates}

All bacterial strains used in this study are listed in Table 1. The isolates of Aeromonas , Streptococcus , andEdwardsiella were cultured in Tryptic Soy Broth (TSB; Becton Dickerson, USA) at $28^{\circ} \mathrm{C}$ while Lactobacillusisolates were cultured in De man, Rogosa, and Sharpe (MRS, HiMedia, India) broth at $37{ }^{\circ} \mathrm{C}$. All laboratory isolates of Aeromonas were previously isolated from diseased fish using selective medium, Rimler-Shotts agar (RS, HiMedia, India) supplemented with Novobiocin (Oxoid, UK), identified by PCR and sequencing of gyr B housekeeping gene (Navarro \& Martínez-Murcia, 2018). Multidrug-resistant strains of $A$. hydrophila (Table S1) were identified based on the method proposed by Magiorakos et al. (2012). 


\section{Phage isolation and morphology}

\section{Preparation of host strain}

The MDR A. hydrophila BT09 (Tables 1 and S1) was chosen as a bacterial host for phage isolation. Prior to phage isolation, prophage induction using Mitomycin C (Sigma-Aldrich, USA) was carried out as described by Walker et al. (2009) to ensure that the host cells do not contain prophage. Briefly, $100 \mu \mathrm{L}$ of bacterial cells suspended in normal saline solution $\left(\mathrm{OD}_{600}=0.6\right)$ was added into each of $10 \mathrm{~mL}$ of TSB supplemented with 250, 500, and 1,000 ng/mL of Mitomycin C. All cultures were incubated at $28^{\circ} \mathrm{C}$ for $8 \mathrm{~h}$. The induced phage production using Mitomycin C was evaluated by the Plaque Drop Assay (Adams, 1959).

\section{Phage isolation}

Water samples were collected from striped catfish culture ponds in Tien Giang Province, Vietnam. The samples were enriched to increase phage concentration according to Van Twest and Kropinski (2009) and isolated by Plaque Assay method described by Jun et al. (2013). Briefly, the samples were centrifuged at $4,500 \mathrm{xg}, 4{ }^{\circ} \mathrm{C}$ for $30 \mathrm{~min}$, and the supernatant was filtered through a $0.2 \mu \mathrm{m}$ filter (Merck Millipore, USA) to remove residual bacteria cells. Then, $10 \mathrm{~mL}$ filtrate was mixed with $10 \mathrm{~mL}$ of A. hydrophila BT09 in TSB supplemented with $1.0 \mathrm{mM} \mathrm{CaCl}_{2}$ and $0.5 \mathrm{mM} \mathrm{MgSO}_{4}(\mathrm{MTSB})$. The mixture was cultured at $28{ }^{\circ} \mathrm{C}$ for 24 $\mathrm{h}$ with $50 \mathrm{rpm}$ shaking. The mixture was then centrifuged at 10,000 $\mathrm{xg}, 4^{\circ} \mathrm{C}$ for $15 \mathrm{~min}$, and the collected supernatant was serially diluted $\left(10^{-1}\right.$ to $\left.10^{-4}\right)$. A volume of $100 \mu \mathrm{L}$ of each dilution was transferred to a tube containing $3.0 \mathrm{~mL}$ of TSA $0.5 \%$ agar supplemented with $1.0 \mathrm{mM} \mathrm{CaCl}_{2}$ and $0.5 \mathrm{mM} \mathrm{MgSO}_{4}(\mathrm{MTSA})$, together with $100 \mu \mathrm{L}$ of $A$. hydrophila. The mixture was vortexed lightly and poured onto a plate of TSA $1.5 \%$ agar. The plates were incubated at $28^{\circ} \mathrm{C}$ for $16 \mathrm{~h}$ and the growth of phages was observed (clear plaque on the plate). The individual clear plaque was picked and aseptically transferred to $200 \mu \mathrm{L}$ of SM buffer (100 $\mathrm{mM} \mathrm{NaCl}, 10 \mathrm{mM} \mathrm{MgSO}$, $50 \mathrm{mM}$ Tris- $\mathrm{HCl}, \mathrm{pH}$ 7.5). The mixture was vortexed vigorously and kept in 4 ${ }^{\circ} \mathrm{C}$ refrigerator overnight. The phages in SM buffer were obtained by filtering the supernatant through a 0.2 $\mu \mathrm{m}$ filter after centrifugation at 10,000 $x \mathrm{~g}$ for $10 \mathrm{~min}$. The filtrate was propagated four times continuously using the same protocol mentioned above for purification of the obtained phages. The isolated phages were stored in SM buffer supplemented with $30 \%$ glycerol at $-80{ }^{\circ} \mathrm{C}$ until used.

\section{Examination of phage morphology}

The structure and size of the phage were determined by Transmission Electron Microscope (TEM). The specific procedure was as follows; the phage solution $(3 \mathrm{~mL})$ was centrifuged twice at 200,000 $x \mathrm{~g}$ for $90 \mathrm{~min}$. The pellets were resuspended in sterile distilled water. A volume of $50 \mu \mathrm{L}$ of $1 \%$ glutaraldehyde (g/vol) was then added to immobilize the sample and rinsed with $0.1 \mathrm{M}$ of cacodylate before proceeding with the dye. The samples were coated with $0.1 \%$ Poly-Lysine solution onto the surface of the 200-mesh carbon-coated grids to increase the adhesion of phages on the mesh. A volume of $10 \mu \mathrm{L}$ of the phages was added to the grid and allowed to dry naturally for $5 \mathrm{~min}$. The samples were dyed with $1 \%$ uranyl acetate sterilized with a $0.2 \mu \mathrm{m}$ filter. The samples were washed with distilled water, allowed to dry for 5 min and imaged with a TEM-JEOL 1010 (Japan) with light projected through the grid for about $5 \mathrm{~s}$ at $80 \mathrm{kV}$. Phage morphology was classified according to the guideline of International Committee on Taxonomy of Viruses (ICTV) and Ackermann (2007).

\subsection{Host range and specificity}

The host range of phage pAh6.2TG isolated in this study was conducted on the collection of $17 \mathrm{~A}$. hydrophila isolates from diseased fish (Tables 1 and S1). In this study, the Plaque Drop Assay was performed as described by Adams (1959) with minor modifications. Briefly, double-layer agar plates containing tested bacterial cells were prepared. Then, $5 \mu \mathrm{L}$ of phages $\left(10^{8} \mathrm{PFU} / \mathrm{mL}\right)$ was dropped on the surface of each plate, kept without moving for $30 \mathrm{~min}$ and incubated at $28^{\circ} \mathrm{C}$ for $16 \mathrm{~h}$. Normal saline solution was used as negative control. Phage susceptibility was indicated by a clear zone appearing at the location of the drops while no clear zone indicated unsusceptible host. Specificity test of phage pAh6.2TG to other common aquatic pathogens (Aeromonas veronii ,Aeromonas schubertii , Edwardsiella ictaluri ,Streptococcus agalactiae ) and probiotic 
bacteria (Lactobacillus fermentum, Lactobacillus plantarum ) (Table 1) was done in the same manner. All tests for host range and specificity were done in triplicates.

\subsection{Phage stability in different environmental conditions}

Stability of phage pAh6.2TG at different temperature $\left(4,25,30,35\right.$, and $\left.40^{\circ} \mathrm{C}\right), \mathrm{pH}(3,5,7,9$ and 11$)$, salinity $\left(0,5,10,20,40\right.$ These tests were carried out by incubating $100 \mu \mathrm{L}$ of phage culture (approx. $10^{9}$ $\mathrm{PFU} / \mathrm{mL}$ ) at the respective temperatures, $\mathrm{pH}$, and salinity for 1 and $24 \mathrm{~h}$ in $10 \mathrm{~mL}$ of $\mathrm{SM}$ buffer. All the experiments were conducted in triplicates. The stability of phages in rearing water was performed in duplicates by adding $2 \mathrm{~mL}$ of phage pAh6.2TG (approx. $\left.8.5 \times 10^{10} \mathrm{PFU} / \mathrm{mL}\right)$ into $50 \mathrm{~L}$ of water $(\mathrm{pH}=$ $7.0 \pm 1.0,0 \% \mathrm{NaCl}$ ) containing 20 of Nile tilapia and maintained at $30 \pm 1.0^{\circ} \mathrm{C}$. The concentration of viable phages was enumerated by plaque assay (Jun et al., 2013). Phage concentration (logPFU/mL) before incubation in different conditions was set to be $100 \%$.

\subsection{Genome characterization}

\section{Phage genome extraction and next-generation sequencing}

The phage particles prepared by liquid propagation in TSBM were desalted using Millipore Amicon ultracentrifugal filter 10,000 NMWL (Merck, United States) at 10,000 $x \mathrm{~g}, 4{ }^{\circ} \mathrm{C}$ for $15 \mathrm{~min}$ and concentrated by ultracentrifugation at $300,000 \times \mathrm{g}, 4^{\circ} \mathrm{C}$ for $3 \mathrm{~h}$ (Beckman Coulter, German). The pellets were resuspended in SM buffer. Phage genomic DNA was extracted using Phage DNA Extraction Kit (Cat. 46800, Norgen Biotek, Canada) following the manufacturer's protocol. Quality and concentration of DNA were measured by Nanodrop (Colibri, German) and Quibit 4.0 (Thermo Scientific, United States). Purified genomic DNA $(3.15 \mathrm{ng} / \mu \mathrm{L})$ was subjected to library preparation and sequencing using Next Generation Sequencing System with Illumina Novaseq 6000 platform (Pair-end, 150; library construction size, 350 bp; data output, 1.0 GB, data quality, Q30 > 80) at KTEST company, Vietnam.

\section{Phage genome assembly and annotation}

Raw reads were filtered using Fastp $v$ 0.20.1 with the qualified phred score [?] Q25 and 8 bases trimming from 5'/3' end (Chen et al., 2018). Host associated sequences were filtered out by mapping trimmed reads to the genome of A. hydrophila type strain (accession no. NZ_CP016990.1) using Bowtie2 v 2.3.4.3 (Langmead \& Salzberg, 2012). Only unaligned reads were subjected to genome assembly using Unicycler $v$ 0.4.8 (Wick et al., 2017) on the Galaxy web platform at usegalaxy.org (Afgan et al., 2016). Potential phage sequence was identified by submitting the assembled contigs to PHASTER web server (Arndt et al., 2016). The predicted phage sequence (assigned as 'pAh6.2TG' in this study) was annotated using Prokka $v$ 1.14.6 with Viruses annotation mode (Seemann, 2014). The annotated phage genome was visualized using DNAplotter (Carver et al., 2009).

\section{Phage taxonomic identification and phylogenetic reconstruction}

Identification of phage species was carried using VICTOR web service (Meier-Kolthoff \& Göker, 2017). VICTOR is a tool that perform pairwise genome comparison of prokaryotic viruses and automatically constructs phylogenomic trees using Genome-BLAST Distance Phylogeny method (GBDP) with the formula D0. This tool also classifies the virus at the species, genus and family level with the taxon boundaries estimating by OPTSIL program (Göker et al., 2009). Herein, only the genomes of the viruses belonging to the family Myoviridae $(n=91)$ were included in this genome comparison since pAh6.2TG was predicted as an unknown Myoviridae by PHASTER tool described in the above section.

In addition to genome comparison, the phylogenetic analyses based on the terminase large subunit (terL) and major capsid protein (MCP) amino acid sequences of pAh6.2TG and other related species (predicted by VICTOR) were also performed via PhyloSuite v1.2.2 (Zhang et al., 2020). Amino acid sequences were aligned using MAFFT (Katoh \& Standley, 2013) and the maximum-likelihood trees were constructed using IQ-TREE (Nguyen et al., 2015) with 5,000 ultrafast bootstraps and best-fit model (LG+G4) estimated by ModelFinder. Phylogenomic tree, terL- and MCP-based trees were visualized using Phandango (Hadfield 
et al., 2018) and iTOL web tools (Letunic \& Bork, 2019). Lastly, the protein sequence similarities between pAh6.2TG and the closest viral taxa were determined using CoreGenes3.5 web server with Blastp threshold score at 75 (Turner et al., 2013).

\section{Effect of phage on Nile tilapia challenged with MDR A. hydrophila}

\section{Experimental fish}

Healthy Nile tilapia $(10.5 \pm 4.7 \mathrm{~g})$ obtained from a commercial tilapia hatchery in Thailand were acclimated for 2 weeks in dechlorinated tap water with aeration at $28 \pm 1.0{ }^{\circ} \mathrm{C}$ before the experiments. The fish were fed with commercial tilapia feed (crude-protein $30 \%$ ) at rate of about $3 \%$ of fish weight twice daily. Before starting the experiments, ten fish were randomly selected for bacterial isolation and found to be free of $A$. hydrophila. The experimental animal protocols were approved by Chulalongkorn University (Approval no. CU-IACUC 2031006).

\section{Fish survivability and sample collection}

This experiment aimed to investigate whether lytic phage treatment improves survivability of Nile tilapia challenged with a pathogenic MDRA. hydrophila BT14. A total of 258 fish were randomly divided into six groups with 2 replicate tanks per each group (Figure S1): Group 1 was exposed to culture medium without phage (no $\mathrm{Ah}+$ no phage); Group 2 was exposed to bacteria without phage (Ah + no phage); Group 3 was exposed to culture medium and phage pAh6.2TG at multiplicity of infection (MOI) $=0.1$ (no Ah + phage 0.1 ); Group 4 was exposed to culture medium and treated with phage at MOI $=1.0$ (no Ah + phage 1.0); Group 5 was challenged with $A$. hydrophila and treated with phage at MOI $=0.1(\mathrm{Ah}+$ phage 0.1$)$; Group 6 was challenged with $A$. hydrophila and treated with phage at MOI $=1.0(\mathrm{Ah}+$ phage 1.0).

In bacterial challenge groups (2, 5 and 6 ), $1 \mathrm{~L}$ of MDR $A$. hydrophila BT14 (approx. $8 \times 10^{8} \mathrm{CFU} / \mathrm{mL}$ ) was added to $50 \mathrm{~L}$ water to reach a final concentration of approx. $2 \times 10^{7} \mathrm{CFU} / \mathrm{mL}$. Groups 5 and 6 tanks had 2 and $20 \mathrm{~mL}$ of phage pAh6.2TG (approx. $8.5 \times 10^{10} \mathrm{PFU} / \mathrm{mL}$ ) added to reach a final concentration of approx. $2 \times 10^{6}$ and $2 \times 10^{7} \mathrm{PFU} / \mathrm{mL}$, respectively. Group 2 tank had $20 \mathrm{~mL}$ of SM buffer without phage added. The mixtures in groups 2,5 and 6 were maintained at $29 \pm 1.0{ }^{\circ} \mathrm{C}$ with aeration for $3 \mathrm{~h}$. In culture medium exposure groups (1, 3 and 4), $1 \mathrm{~L}$ of TSB was added to $50 \mathrm{~L}$ water. Groups 3 and 4 tanks had 2 and $20 \mathrm{~mL}$ of phage pAh6.2TG (approx. $8.5 \times 10^{10} \mathrm{PFU} / \mathrm{mL}$ ) added, respectively. After $3 \mathrm{~h}$, the fish were transferred to all groups, maintained at $29 \pm 1^{\circ} \mathrm{C}$ with aeration for 14 days. In order to investigate the effect of phage on the concentration of $A$. hydrophila in rearing water, a volume of $25 \mathrm{~mL}$ water from groups 2,5 and 6 were sampled at 3,24 and $48 \mathrm{~h}$ after exposure with phage. A volume of $1 \mathrm{~mL}$ water was centrifuged at $4{ }^{\circ} \mathrm{C}$, $10.000 \times \mathrm{g}$, for $5 \mathrm{~min}$. The supernatant were collected and diluted in SM buffer to measure concentration of phage by Plaque Assay method (Jun et al., 2013). The pellet was washed 1 time and re-suspended in $1 \mathrm{~mL}$ of PBS buffer. Bacterial concentration was then enumerated by conventional plate count method using RS supplemented with Novobiocin (Harrigan \& McCance, 2014). In order to investigate the effect of phage on the concentration of $A$. hydrophila in liver, two fish from groups 2, 5 and 6 were sampled at 24,48 and $72 \mathrm{~h}$ after exposure with phage. The fish were necropsied, and $0.1 \mathrm{~g}$ of live tissue was collected and homogenized in a microtube containing $900 \mu \mathrm{L}$ of SM buffer. The samples were then centrifuged at $10.000 \mathrm{x} g$, for $5 \mathrm{~min}$. The supernatant and pellet were used for respective phage and bacterial enumeration same as above.

The remaining fish were observed daily for 14 days, and mortality was recorded. Representative moribund or freshly dead fish were collected for bacterial re-isolation using RS supplemented with Novobiocin as described above. The RPS was calculated according to the formula described by Ellis (1988): RPS = (1 - \% mortality in challenge / $\%$ mortality in control) $* 100$.

\section{Determination of serum antibody by the enzyme-linked immunosorbent assay (ELISA)}

For the comparison of specific antibody (IgM) levels against A. hydrophila between experimental groups, blood samples of 5 surviving fish in each tank (10 fish/group) were collected at the end of the experiment (day 14). Sera were collected after centrifugation at 8,000 x g for $15 \mathrm{~min}$, stored at $-20{ }^{\circ} \mathrm{C}$ until used. ELISA assay was carried out following the protocol described by Dien et al. (2021). 


\section{Statistical Analysis}

Percent survival data from the challenge experiments was analyzed by the Kaplan-Meier method and differences among groups were tested using a log-rank test, $p$-values of 0.05 or less were considered to be statistically significant. Enumeration of $A$. hydrophilaconcentration and phage titer in rearing water and fish liver samples was analyzed by ANOVA. Dunnett post-hoc test was used to measure specific differences between pairs of mean. The $\mathrm{OD}_{450 \mathrm{~nm}}$ readings from the indirect ELISA assay were analyzed using a KruskalWallis test. Multiple comparison analyses were performed by Bonferroni test. All statistical analyses were performed using SPSS Software ver22.0 (IBM Corp., USA).

\section{RESULTS}

\section{Prophage induction, phage isolation, and morphology}

Although three doses of Mitomycin C $(250,500$, and 1,000 ng/mL) were used for prophage induction, no plaque was detected, indicating that $A$. hydrophila BT09 did not contain prophage and was suitable as a bacterial host for lytic phage isolation. Subsequently, a phage, designated pAh6.2TG, was isolated from a freshwater sample. Phage pAh6.2TG produced medium, clear, and round plaques with diameter of 1.31 .8 $\mathrm{mm}$ (Figure 1A-B) after $16 \mathrm{~h}$ of incubation. TEM morphology examination showed that the phage had an icosahedral head with $59.6 \pm 2.5 \mathrm{~nm}$ diameter $(\mathrm{n}=3)$ and a contractile tail which was $137 \pm 10.2 \mathrm{~nm}$ in length and $20.2 \pm 2.7 \mathrm{~nm}$ in diameter $(\mathrm{n}=3$ ) (Figure 1C-D). Based on the morphological features, phage pAh6.2TG was initially classified to the Myoviridae family.

\section{Host range and specificity of phage pAh6.2TG}

Among all bacterial isolates tested, pAh6.2TG showed lytic activity against 10/17 A. hydrophila isolates (Table 1) of which 8 isolates were MDR (Table S1). In contrast, no lytic activity was observed against other fish bacterial pathogens including A. veronii, A. schubertii, E. ictaluri, S. agalactiae as well as two probiotic bacteria L. fermentum, and L. plantarum (Table 1).

\section{Stability of phage pAh6.2TG at different environmental conditions}

Stability of pAh6.2TG at different temperatures $\left(4\right.$ to $\left.40^{\circ} \mathrm{C}\right)$ is shown in Figure 2A. Similar percentages of viable phage were detected after $1 \mathrm{~h}(96 \pm 0.55-99.6 \pm 0.08 \%)$ and $24 \mathrm{~h}(93 \pm 0.23-98.6 \pm 0.17 \%)$ of incubation, indicating that pAh6.2TG is a relatively thermostable phage.

Phage pAh6.2TG was stable $(93.5 \pm 1.69-97 \pm 0.87 \%)$ at $\mathrm{pH} 7,9$ and 11 (Figure 2B). However, the phage pAh6.2TG was not stable at low $\mathrm{pH}$. At $\mathrm{pH} 5,93 \pm 0.24 \%$ phage remained viable after $1 \mathrm{~h}$, and decreased sharply to $32.7 \pm 0.44 \%$ (from 7.88 to $2.58 \pm 0.06 \log \mathrm{PFU} / \mathrm{mL}$ ) after $24 \mathrm{~h}$. At pH 3, only $15.2 \pm 1.47 \%$ (1.19 $\pm 0.2 \log \mathrm{PFU} / \mathrm{mL}$ ) of phage was still viable after $1 \mathrm{~h}$ and reduced to undetectable level at $24 \mathrm{~h}$ (Figure $2 \mathrm{~B}$ ).

Phage pAh6.2TG was relatively stable at a wide range of salinity ( 0 - 40 viable after 1 and $24 \mathrm{~h}$, respectively (Figure 2C).

In fish-rearing water $\left(30+-1{ }^{\circ} \mathrm{C}, \mathrm{pH} 6.9,0 \% \mathrm{NaCl}\right)$ spiked with phages, percentage of stability at 1 and 3 $\mathrm{h}$ were $99.5+-0.15 \%$ and $98.6+-0.11 \%$, respectively. After 24 and $48 \mathrm{~h}$, phage titer decreased slightly to $91.9+-0.85 \%$ and $91.3+-0.5 \%$, equivalent to $6.52+-0.07$ and $6.47+-0.03 \operatorname{logPFU} / \mathrm{mL}$, respectively.

\section{Genome characterization of pAh6.2TG phage}

Based on the assembly graph generated by Unicycler software, pAh6.2TG was predicted to contain a circular genome with a length of $51,780 \mathrm{bp}$, a GC content of $52.48 \%$, encoding 65 putative open reading frames (ORFs) (Table S2) without tRNA genes (Figure 3). According to bioinformatics prediction, pAh6.2TG genome consists of three main functional modules: i) phage structure and DNA packaging (major capsid protein, baseplate protein, tail fiber protein, and terminase subunit), ii) DNA metabolism and replication (RNA polymerase, DNA polymerase, DNA helicase, 5'-3' exonuclease, DNA ligase, and Ribonucleosidediphosphate reductase large subunit), and iii) host lysis (cell wall hydrolase). 
The closest phage taxonomic classification of pAh6.2TG toward other 91Myoviridae phages in the public database revealed thatAeromonas phage pAh6.2TG and PVN02 (accession no. LR813619) were classified as the identical species with $99.33 \%$ identity. The result also showed total $64 / 65$ ORFs were homologous between pAh6.2TG and PVN02 (97.3 - $100 \%$ nt. identity), except for ORF03 that showed the highest homology (70\%) to another Aeromonas phage pAh6-C (Table S2). Phylogenetic analysis based on whole genome (Figure 4A-B), major capsid protein sequence (Figure 4C), and terminase large subunit sequence (Figure 4D) confirmed high homology of phage pAh6.2TG and phage PVN02. In addition, pAh6.2TG was closely related to the Aeromonas phage pAh6-C (accession no. KJ858521), Shewanella phage Spp001 (accession no. NC023594), and Shewanella phage SppYZU05 (accession no. NC047824) (Figure 4).

\section{In vivo challenge results}

Phage pAh6.2TG improved survivability of Nile tilapia challenged with the MDR A. hydrophila

In vivo experiment showed that $100 \%$ fish in negative control group (no $\mathrm{Ah}+$ no phage) survived after 14 days, while only $25 \%$ survival was recorded in positive control group (Ah + no phage) (Figure 5). Interestingly, there was $62.5 \%$ and $80 \%$ survival in groups treated with pAh6.2TG with MOI $=0.1$ (Ah + phage 0.1$)$ and $\mathrm{MOI}=1.0(\mathrm{Ah}+$ phage 1.0), respectively. These differences in percentage of survival of 2 phage treated groups were not statistically significant $(p=0.154)$ but statistically significant with positive control group $(p=0.000)$. The remaining two groups treated with phage without bacteria had 95 $-100 \%$ survival. The relative percent survival (RPS) of two treatments groups were $50 \%(\mathrm{MOI}=0.1)$ and $73.3 \%$ (MOI $=1)$, respectively. The moribund fish in challenge groups showed behavioral abnormalities (lethargy, loss of appetite, and surface swimming) and pale liver. Using selective medium, pure colonies with morphological characteristics of $A$. hydrophila were successfully isolated from representative dead fish ( $\mathrm{n}=3)$.

Phage pAh6.2TG suppressed bacterial concentration in water and fish tissue

Fluctuation of bacterial concentration and phage titer in water and fish liver are shown in Figure 6 and Table S3. In rearing water, after $3 \mathrm{~h}$ of bacteria and phages exposure, bacterial concentration reduced 6.7 +-0.5 folds in group treated with phage MOI $=0.1$, and $18.1+-6.98$ folds in group treated with phage MOI $=1.0$ (Figure 6A). The calculation of fold changes is displayed in Table S3. In contrast, after $3 \mathrm{~h}$, bacterial concentration increased $10.2+-3.15$ folds in $\mathrm{Ah}+$ no phage group. Simultaneously, phage titer in groups treated with phage MOI $=0.1$ and 1.0 after $3 \mathrm{~h}$ increased $51.04+-5.16$ folds, and $20.98+-1.03$ folds, respectively (Figure 6B). Phage was absent in $\mathrm{Ah}+$ no phage control group. At $24 \mathrm{~h}$ post-challenge, bacterial concentration in three groups was increased, while phage concentration in water slightly decreased. Besides, slight reduction of bacterial and phage concentration was observed in all groups at $48 \mathrm{~h}$ post-treatment (Figure 6A-B).

Moreover, in fish liver, bacterial concentrations of $5.8+-0.14,5.52+-0.06,5.51+-0.24 \log \mathrm{CFU} / \mathrm{g}$ were recorded in $\mathrm{Ah}+$ no phage, $\mathrm{Ah}+$ phage 0.1 , and $\mathrm{Ah}+$ phage 1.0 groups, respectively (Figure $6 \mathrm{C}$ ). In $\mathrm{Ah}+$ phage 0.1 and $\mathrm{Ah}+$ phage1.0 groups, phage titers were $4.55+-0.2$ and $4.75+-0.12 \operatorname{logPFU} / \mathrm{g}$, respectively (Figure 6D). Similar pattern of phage concentration in rearing water was observed at $48 \mathrm{~h}$ post-challenge, while bacterial load decreased in all groups. In fish liver, compared to $24 \mathrm{~h}$ post-treatment, bacterial concentration in $\mathrm{Ah}+$ no phage groups increased $10.69+-3.85$ folds, while in $\mathrm{Ah}+$ phage 0.1 and $\mathrm{Ah}+$ phage 1.0 groups, bacteria decreased $2.7+-0.24$ and $34.08+-26.4$ folds, respectively (Table S3).

The bacterial load in fish liver of $\mathrm{Ah}+$ no phage group decreased $3.8+-0.64$ folds, from $6.58 \times 10^{6}+-3.18$ x $10^{5}$ at $24 \mathrm{~h}$ post-challenge to $1.75 \times 10^{6}+-2.12 \times 10^{5} \mathrm{CFU} / \mathrm{g}$ at $72 \mathrm{~h}$ post-challenge (Table S3). The same pattern was recorded in $\mathrm{Ah}+$ phage 0.1 and $\mathrm{Ah}+$ phage 1.0 groups with $4.03+-0.83$ and $2.18+-0.96$ fold-reduction, respectively (Table S3). At $72 \mathrm{~h}$ post-challenge, phage titer in fish liver decreased $15.13+-$ 3.35 and $13.96+-3.95$ folds in groups treated with phage 0.1 and 1.0 at $24 \mathrm{~h}$ post-challenge, respectively (Table S3).

Surviving fish developed specific IgM against MDRA. hydrophila

All surviving fish in three groups challenged with MDR A. hydrophila had significantly higher levels of 
specific antibody (IgM) compared to the three unchallenged groups $(p<0.05)$ as measured by indirect ELISA, Kruskal - Wallis test: H $(5)=35.218, p=0.000$ (Figure 7). The serum from fish in the Ah + no phage, Ah + phage 0.1, and Ah + phage 1.0 groups had OD readings of $0.18+-0.09,0.22+-0.17$, and $0.22+-0.12$, respectively. The IgM level was slightly higher in 2 phage treated groups but not statistically significant difference. In contrast, the low level of $\mathrm{OD}_{450}$ readings were recorded in the remaining groups (0.06 +- 0.003 to $0.08+-0.03)$ (Figure 7$)$.

\section{DISCUSSION}

The Myoviridae phages specific to A. hydrophila are highly diverse in nature (Chandrarathna et al., 2020; Cheng et al., 2021; Jun et al., 2013). The lytic pAh6.2TG isolated in this study had genome characteristics most closely related to phage PVN02 (99.33\% nt. identity) in the GenBank database, previously isolated from Vietnam (Tu et al., 2020). The origins of two phages from the closed geographical area of Mekong basin, although from different rivers, may explain the high genomic similarity of pAh6.2TG and PVN02. Compared to previously reported A. hydrophila -specific phages, pAh6.2TG (51,780 bp) had similar genome size with the phage PVN02 (51,668 bp) from Vietnam (Tu et al., 2020), and pAh6-C (53,744 bp) from Korea (Jun et al., 2015), but is larger than phage AhyVDH1 (39,175 bp) from China (Cheng et al., 2021), and smaller than phage LAh10 (260,310 bp) from Australia. The latter is the largest known phage infecting A. hydrophila (Kabwe et al., 2020). Genome analysis indicated that pAh6.2TG does not contain potential virulent genes or antimicrobial resistant genes, suggesting it is highly relevant as a biocontrol agent in aquaculture systems without concern of antimicrobial-resistant gene transmission.

Climate change has affected aquaculture environments by perturbing chemical and physical properties of water, particularly in the increase of water temperature and salinization (Maulu et al., 2021; Seggel \& De Young, 2016). The stability of pAh6.2TG under a wide range of temperatures $\left(4-40^{{ }^{d e g}} \mathrm{C}\right)$ and salinity $(0-40 \mathrm{ppt})$ might be important characteristics for its wider application in diverse aquaculture environments. Relatively high stability of pAh6.2TG in fish-rearing water suggests that immersion route is practical. However, low viability of pAh6.2TG at $\mathrm{pH} 3-5$ suggests that oral administration might not be applicable due to the low $\mathrm{pH}$ in gastrointestinal tract of aquatic animals, e.g. $\mathrm{pH}$ in Nile tilapia stomach range from $1.4-2.0$ (Moriarty, 1973).

One of the major limitations of phage application is its narrow host range and geographical specificity (Culot et al., 2019; Perez-Sanchez et al., 2018; Ross et al., 2016). Although the newly isolated phage pAh6.2TG could lyse multiple isolates of MDR A. hydrophila from Vietnam, however, it does not lyse the isolates from Thailand and other bacterial species from the same or different genera. Therefore, to expand wider application of phage in aquaculture, a cocktail of multiple phage strains from different geographical locations might be the better approach to tackle not only AMR A. hydrophila but also other important bacterial pathogens in freshwater fishes. In addition, the specific infection of pAh6.2TG to A. hydrophila and not probiotic bacteria suggest the potential combination of phage therapy and probiotics to combat MDR A. hydrophila infection in aquaculture.

Carps, tilapias, and catfishes are crucial inland freshwater fish that play a vital role for food system transformation to tackle micronutrient deficiencies in LMICs (FAO, 2020; Hicks et al., 2019). A. hydrophila infection is one of the most important bacterial diseases responsible for the loss of millions of dollars in the global freshwater aquaculture industry (Hossain et al., 2014; Peterman \& Posadas, 2019; Pridgeon \& Klesius, 2012). Increasing prevalence of pathogenic MDRA. hydrophila in aquaculture poses the high risk for serious uncontrollable disease outbreaks and public health concern due to spread of AMR. Non-antibiotic approach using lytic phages, therefore, was explored to control disease caused by MDR A. hydrophila in aquaculture systems. In this study, we provided in vivo evidences for the efficacy of phage application in rearing water which is effective at suppressing bacterial concentration in water as well as reducing the bacterial load in fish liver. The presence of phages in the fish liver also suggests that immersion administration could deliver considerably large number of phages into the fish tissue. These factors may contribute to improvement of survivability (RPS $=50-75 \%$ ) of tilapia. Importantly, not only was there higher survival in phage treated groups, but all surviving fish also developed specific IgM against A. hydrophila. This suggests that phages 
possibly weakened the bacteria which allowed the fish immune system to respond more effectively and saved the fish from death. Similarly, there were several studies using phages as therapeutic agent to control $A$. hydrophila infection. Le et al. (2018) used phage cocktails (F2 and F5) with MOI =0.01, 1.0, and 100 to control A. hydrophila infection in striped catfish (Pangasianodon hypophthalmus) by injection administration and obtained RPS of $16.33 \%, 44.9 \%$, and $100 \%$, respectively. Immersion treatment of $1 \times 10^{8} \mathrm{PFU} / \mathrm{mL}$ phage Akh-2 improved survivability of Nile tilapia with RPS of 41.1\% (Akmal et al., 2020). Cao et al. (2020) applied phage MJG by injection, immersion, and oral administration to control a pathogenic A. hydrophila in rainbow trout and the fish gained RPS of $100 \%, 66.7 \%$, and 50\%, respectively. Dang et al. (2021) showed protective efficacy of phage PVN02-sprayed feed against $A$. hydrophila $4.4 \mathrm{~T}$ in striped catfish with RPS from $75.6-87.8 \%$.

The findings in this study suggest a potential approach using phage as prophylactic agent that was effective in protecting Nile tilapia from a MDR A. hydrophila. This approach provided comparable RPS to other promising alternatives to antibiotics, such as probiotic-based or plant-based products (Dawood et al., 2020; Kuebutornye et al., 2020; Naliato et al., 2021; Neamat-Allah et al., 2021). Apart from tilapia, pAh6.2TG has great potential to be applied in catfish aquaculture industry due to the lytic activity of pAh6.2TG against multiple MDRA. hydrophila strains isolated from diseased striped catfish.

In summary, this study reported a newly isolated lytic phage pAh6.2TG that infects several isolates of MDR A. hydrophila . The phage was classified as a member of Myoviridae based on a combination of morphology and genomic characterization. In vitro tests showed that pAh6.2TG was relatively stable at different environmental conditions. Using this phage as prophylactic agent was successful at reducing mortality in Nile tilapia. Phage pAh6.2TG application in rearing water not only suppressed MDR A. hydrophila loads in the rearing water and colonization of the bacteria in fish liver, but also improved fish survivability. These findings supported that pAh6.2TG could be used in rearing water for biocontrol of MDR A. hydrophila infection towards sustainable aquaculture.

\section{NUCLEOTIDE SEQUENCE DATA}

Phage pAh6.2TG sequence data has been submitted to the GeneBank databases under accession number MZ336020.

\section{ACKNOWLEDGEMENTS}

Le Thanh Dien received the scholarships of Chulalongkorn University for ASEAN and NON-ASEAN countries, and the $90^{\text {th }}$ Anniversary of Chulalongkorn University Scholarship. Channarong Rodkhum was supported by Thailand Science Research and Innovation (TSRI) Fund, Chulalongkorn University_FRB640001_01_31_6. Ha Thanh Dong was supported by UK Government - Department of Health and Social Care (DHSC), Global AMR Innovation fund (GAMRIF) and the International Development Research Center (IDRC), Ottawa, Canada. We would like to acknowledge Kamphaengsaen Fisheries Research Station, Faculty of Fisheries, Kasetsart University, Thailand for providing experimental fish.

\section{CONFLICT OF INTEREST}

The authors declare that there are no conflicts of interest.

\section{AUTHOR CONTRIBUTION STATEMENT}

Le Thanh Dien : Conceptualization, Methodology, Investigation, Formal analysis, Writing - original draft. Le Buu Ky : Investigation. Bui The Huy : Investigation. Pattanapon Kayansamruaj: Methodology, Data analysis. Mohammad Fadhlullah Mursalim: Investigation. Saengchan Senapin : Data curation, Review \& Editing. Channarong Rodkhum : Supervision, Validation, Review \& Editing. Ha Thanh Dong : Conceptualization, Data curation, Writing Review \& Editing, Supervision, and Validation.

\section{ETHICAL APPROVAL}

The authors confirm that the ethical policies of the journal, as noted on the journal's author guidelines 
page, have been adhered to and the appropriate ethical review committee approval has been received. This project has been reviewed and approved by the Institutional Animal Care and Use Committee (IACUC) in accordance with university regulations and policies governing the care and use of laboratory animals. The review has followed guidelines documented in Ethical Principles and Guidelines for Use of Animals for Scientific Purposes edited by the National Research Council of Thailand.

\section{DATA AVAIBILITY STATEMENT}

The data that support the findings of this study are available on request.

\section{References}

Ackermann, H.-W. (2007). 5500 Phages examined in the electron microscope. Archives of Virology, 152 (2), 227-243. https://doi.org/10.1007/s00705-006-0849-1

Adams, M. H. (1959). Bacteriophages. Bacteriophages (pp. 443-522): Wiley Intersciences, New York

Afgan, E., Baker, D., Van den Beek, M., Blankenberg, D., Bouvier, D., Čech, M., . . . Eberhard, C. (2016). The Galaxy platform for accessible, reproducible and collaborative biomedical analyses: 2016 update. Nucleic Acids Research, 44 (W1), W3-W10. https://doi.org/10.1093/nar/gkw343

Akmal, M., Rahimi-Midani, A., Hafeez-ur-Rehman, M., Hussain, A., \& Choi, T.-J. (2020). Isolation, characterization, and application of a bacteriophage infecting the fish pathogen Aeromonas hydrophila .Pathogens, 9 (3), 215. https://doi.org/10.3390/pathogens9030215

Anand, T., Vaid, R. K., Bera, B. C., Singh, J., Barua, S., Virmani, N., . . . Tripathi, B. (2016). Isolation of a lytic bacteriophage against virulent Aeromonas hydrophila from an organized equine farm. Journal of Basic Microbiology, 56 (4), 432-437. https://doi.org/10.1002/jobm.201500318

Arndt, D., Grant, J. R., Marcu, A., Sajed, T., Pon, A., Liang, Y., \& Wishart, D. S. (2016). PHASTER: a better, faster version of the PHAST phage search tool. Nucleic Acids Research, 44 (W1), W16-W21. https://doi.org/10.1093/nar/gkw387

Cao, Y., Li, S., Han, S., Wang, D., Zhao, J., Xu, L., . . . Lu, T. (2020). Characterization and application of a novel Aeromonasbacteriophage as treatment for pathogenic Aeromonas hydrophilainfection in rainbow trout. Aquaculture, 523 , 735193. https://doi.org/10.1016/j.aquaculture.2020.735193

Cao, Y., Zhang, Y., Lan, W., \& Sun, X. (2021). Characterization of vB_VpaP_MGD2, a newly isolated bacteriophage with biocontrol potential against multidrug-resistant Vibrio parahaemolyticus .Archives of Virology, 166 (2), 413-426. https://doi.org/10.1007/s00705-020-04887-x

Carver, T., Thomson, N., Bleasby, A., Berriman, M., \& Parkhill, J. (2009). DNAPlotter: circular and linear interactive genome visualization. Bioinformatics, 25 (1), 119-120. https://doi.org/10.1093/bioinformatics/btn578

Chandrarathna, H., Nikapitiya, C., Dananjaya, S., De Silva, B., Heo, G.-J., De Zoysa, M., \& Lee, J. (2020). Isolation and characterization of phage AHP-1 and its combined effect with chloramphenicol to controlAeromonas hydrophila . Brazilian Journal of Microbiology, 51 (1), 409-416. https://doi.org/10.1007/s42770-019-00178-z

Chen, S., Zhou, Y., Chen, Y., \& Gu, J. (2018). fastp: an ultra-fast all-in-one FASTQ preprocessor. Bioinformatics, 34 (17), i884-i890. https://doi.org/10.1093/bioinformatics/bty560

Cheng, Y., Gao, D., Xia, Y., Wang, Z., Bai, M., Luo, K., . . . Xiao, W. (2021). Characterization of novel bacteriophage AhyVDH1 and its lytic activity against Aeromonas hydrophila. Current Microbiology, 78 (1), 329-337. https://doi.org/10.1007/s00284-020-02279-7

Cui, H., Cong, C., Wang, L., Li, X., Li, J., Yang, H., . . . Xu, Y. (2021). Protective effectiveness of feeding phage cocktails in controlling Vibrio harveyi infection of turbot Scophthalmus maximus. Aquaculture, 535 
, 736390. https://doi.org/10.1016/j.aquaculture.2021.736390

Culot, A., Grosset, N., \& Gautier, M. (2019). Overcoming the challenges of phage therapy for industrial aquaculture: A review.Aquaculture, 513 , 734423. https://doi.org/10.1016/j.aquaculture.2019.734423

da Silva, B. C., Mouriño, J. L. P., Vieira, F. N., Jatobá, A., Seiffert, W. Q., \& Martins, M. L. (2012). Haemorrhagic septicaemia in the hybrid surubim (Pseudoplatystoma corruscans $\times$ Pseudoplatystoma fasciatum ) caused by Aeromonas hydrophila . Aquaculture Research, 43 (6), 908-916. https://doi.org/10.1111/j.13652109.2011.02905.x

Dang, T. H. O., Xuan, T. T. T., Duyen, L. T. M., Le, N. P., \& Hoang, H. A. (2021). Protective efficacy of phage PVN02 against haemorrhagic septicaemia in striped catfish Pangasianodon hypophthalmus via oral administration. Journal of Fish Diseases, n/a (n/a). https://doi.org/10.1111/jfd.13387

Dawood, M. A., Moustafa, E. M., Elbialy, Z. I., Farrag, F., Lolo, E. E., Abdel-Daim, H. A., . . Van Doan, H. (2020). Lactobacillus plantarum L-137 and/or $\beta$-glucan impacted the histopathological, antioxidant, immunerelated genes and resistance of Nile tilapia (Oreochromis niloticus) against Aeromonas hydrophila .Research in Veterinary Science, 130 , 212-221. https://doi.org/10.1016/j.rvsc.2020.03.019

Dien, L. T., Vu Linh, N., Sangpo, P., Senapin, S., St-Hilaire, S., Rodkhum, C., \& Dong, H. T. (2021). Ozone nanobubble treatments improve survivability of Nile tilapia (Oreochromis niloticus ) challenged with a pathogenic multidrug-resistant Aeromonas hydrophila .Journal of Fish Diseases, n/a (n/a). https://doi.org/ $10.1111 /$ jfd. 13451

Donati, V. L., Dalsgaard, I., Sundell, K., Castillo, D., Er-Rafik, M., Clark, J., . . . Madsen, L. (2021). Phage-mediated control of Flavobacterium psychrophilum in Aquaculture: In vivoexperiments to compare delivery methods. Frontiers in Microbiology, 12 , 438. https://doi.org/10.3389/fmicb.2021.628309

Dong, H., Techatanakitarnan, C., Jindakittikul, P., Thaiprayoon, A., Taengphu, S., Charoensapsri, W., . . . Senapin, S. (2017).Aeromonas jandaei and Aeromonas veronii caused disease and mortality in Nile tilapia, Oreochromis niloticus (L.).Journal of Fish Diseases, 40 (10), 1395-1403. https://doi.org/10.1111/jfd.12617

Dong, H. T., Nguyen, V. V., Le, H. D., Sangsuriya, P., Jitrakorn, S., Saksmerprome, V., . . Rodkhum, C. (2015). Naturally concurrent infections of bacterial and viral pathogens in disease outbreaks in cultured Nile tilapia (Oreochromis niloticus) farms.Aquaculture, 448 , 427-435. https://doi.org/10.1016/j.aquaculture.2015.06.027

Dong, H. T., Nguyen, V. V., Phiwsaiya, K., Gangnonngiw, W., Withyachumnarnkul, B., Rodkhum, C., \& Senapin, S. (2015). Concurrent infections of Flavobacterium columnare and Edwardsiella ictaluri in striped catfish, Pangasianodon hypophthalmus in Thailand. Aquaculture, 448, 142-150. https://doi.org/10.1016/j.aquaculture.2015.05.046

Easwaran, M., Dananjaya, S., Park, S., Lee, J., Shin, H., \& De Zoysa, M. (2017). Characterization of bacteriophage pAh-1 and its protective effects on experimental infection of Aeromonas hydrophila in Zebrafish (Danio rerio ). Journal Fish Diseases, 40 , 841-846. https://doi.org/10.1111/jfd.12536

Ellis, A. (1988). General principals of fish vaccination. Fish vaccination (pp. 1-19): Academic Press, New York

FAO. (2020). The State of World Fisheries and Aquaculture 2020 - Meeting the sustainable development goals. Fisheries and Aquaculture Department, Food and Agriculture Organization of the United Nations, Rome. https://doi.org/10.4060/ca9229en

Göker, M., García-Blázquez, G., Voglmayr, H., Tellería, M. T., \& Martín, M. P. (2009). Molecular taxonomy of phytopathogenic fungi: a case study in Peronospora . PLoS One, 4 (7), e6319. https://dx.doi.org/10.1371\%2Fjournal.pone.0006319 
Guz, L., \& Kozinska, A. (2004). Antibiotic susceptibility of Aeromonas hydrophila and A. sobria isolated from farmed carp (Cyprinus carpio L.). Bulletin of the Veterinary Institute in Pulawy, 48 , 391-395.

Hadfield, J., Croucher, N. J., Goater, R. J., Abudahab, K., Aanensen, D. M., \& Harris, S. R. (2018). Phandango: an interactive viewer for bacterial population genomics. Bioinformatics, 34 (2), 292-293. http://dx.doi.org/10.1093/bioinformatics/btx610

Harrigan, W. F., \& McCance, M. E. (2014). Laboratory Methods in Microbiology : Elsevier Science.

Hicks, C. C., Cohen, P. J., Graham, N. A., Nash, K. L., Allison, E. H., D’Lima, C., . . Thorne-Lyman, A. L. (2019). Harnessing global fisheries to tackle micronutrient deficiencies. Nature, 574 (7776), 95-98. https://doi.org/10.1038/s41586-019-1592-6

Hoang, H. A., Xuan, T. T. T., Nga, L. R., \& Oanh, D. T. H. (2019). Selection of phages to control Aeromonas hydrophila - An infectious agent in striped catfish. Biocontrol Science, 24 (1), 23-28. https://doi.org/10.4265/bio.24.23

Hoelzer, K., Bielke, L., Blake, D. P., Cox, E., Cutting, S. M., Devriendt, B., . . Lemiere, S. (2018). Vaccines as alternatives to antibiotics for food producing animals. Part 1: challenges and needs. Veterinary Research, 49 (1), 64. https://doi.org/10.1186/s13567-018-0560-8

Hossain, M. J., Sun, D., McGarey, D. J., Wrenn, S., Alexander, L. M., Martino, M. E., . . Liles, M. R. (2014). An Asian origin of virulentAeromonas hydrophila responsible for disease epidemics in United States-farmed catfish. MBio, 5 (3), e00848-00814. https://doi.org/10.1128/mBio.00848-14

Jhunkeaw, C., Khongcharoen, N., Rungrueng, N., Sangpo, P., Panphut, W., Thapinta, A., . . . Dong, H. T. (2021). Ozone nanobubble treatment in freshwater effectively reduced pathogenic fish bacteria and is safe for Nile tilapia (Oreochromis niloticus ). Aquaculture, 534, 736286 . https://doi.org/10.1016/j.aquaculture.2020.736286

Jun, J. W., Kim, H. J., Yun, S. K., Chai, J. Y., \& Park, S. C. (2015). Genomic structure of the Aeromonas bacteriophage pAh6-C and its comparative genomic analysis. Archives of Virology, 160 (2), 561-564. https://doi.org/10.1007/s00705-014-2221-1

Jun, J. W., Kim, J. H., Shin, S. P., Han, J. E., Chai, J. Y., \& Park, S. C. (2013). Protective effects of the Aeromonas phages pAh1-C and pAh6-C against mass mortality of the cyprinid loach (Misgurnus anguillicaudatus ) caused by Aeromonas hydrophila .Aquaculture, 416 , 289-295. https://doi.org/10.1016/j.aquaculture.2013.09.045

Kabwe, M., Brown, T., Speirs, L., Ku, H., Leach, M., Chan, H. T., . . Tucci, J. (2020). Novel bacteriophages capable of disrupting biofilms from clinical strains of Aeromonas hydrophila. Frontiers in Microbiology, 11 , 194. https://doi.org/10.3389/fmicb.2020.00194

Katoh, K., \& Standley, D. M. (2013). MAFFT multiple sequence alignment software version 7: improvements in performance and usability.Molecular Biology and Evolution, 30 (4), 772-780. https://doi.org/10.1093/molbev/mst010

Kuebutornye, F. K., Wang, Z., Lu, Y., Abarike, E. D., Sakyi, M. E., Li, Y., . . Hlordzi, V. (2020). Effects of three host-associatedBacillus species on mucosal immunity and gut health of Nile tilapia, Oreochromis niloticus and its resistance against Aeromonas hydrophila infection. Fish 85 Shellfish Immunology, 97 , 83-95. https://doi.org/10.1016/j.fsi.2019.12.046

Kutateladze, M., \& Adamia, R. (2010). Bacteriophages as potential new therapeutics to replace or supplement antibiotics. Trends in Biotechnology, 28 (12), 591-595. https://doi.org/10.1016/j.tibtech.2010.08.001

Langmead, B., \& Salzberg, S. L. (2012). Fast gapped-read alignment with Bowtie 2. Nature Methods, 9 (4), 357. https://doi.org/10.1038/nmeth.1923 
Le, T. S., Nguyen, T. H., Vo, H. P., Doan, V. C., Nguyen, H. L., Tran, M. T., . . Kurtboke, D. I. (2018). Protective fffects of bacteriophages against Aeromonas hydrophila species Causing Motile Aeromonas Septicemia (MAS) in striped catfish. Antibiotics (Basel), 7 (1). doi:10.3390/antibiotics7010016

Letunic, I., \& Bork, P. (2019). Interactive Tree Of Life (iTOL) v4: recent updates and new developments. Nucleic Acids Research, 47 (W1), W256-W259. https://doi.org/10.1093/nar/gkz239

Luo, X., Liao, G., Liu, C., Jiang, X., Lin, M., Zhao, C., . . Huang, Z. (2018). Characterization of bacteriophage HN 48 and its protective effects in Nile tilapia Oreochromis niloticus againstStreptococcus agalactiae infections. Journal of Fish Diseases, 41 (10), 1477-1484. https://doi.org/10.1111/jfd.12838

Magiorakos, A.-P., Srinivasan, A., Carey, R., Carmeli, Y., Falagas, M., Giske, C., . . . Olsson-Liljequist, B. (2012). Multidrug-resistant, extensively drug-resistant and pandrug-resistant bacteria: an international expert proposal for interim standard definitions for acquired resistance. Clinical Microbiology and Infection, 18 (3), 268-281. https://doi.org/10.1111/j.1469-0691.2011.03570.x

Maulu, S., Hasimuna, O. J., Haambiya, L. H., Monde, C., Musuka, C. G., Makorwa, T. H., . . Nsekanabo, J. D. (2021). Climate change effects on aquaculture production: sustainability implications, mitigation, and adaptations. Frontiers in Sustainable Food Systems, 5 , 70. https://doi.org/10.3389/fsufs.2021.609097

Meier-Kolthoff, J. P., \& Göker, M. (2017). VICTOR: genome-based phylogeny and classification of prokaryotic viruses.Bioinformatics, 33 (21), 3396-3404. https://doi.org/10.1093/bioinformatics/btx440

Moriarty, D. (1973). The physiology of digestion of blue-green algae in the cichlid fish, Tilapia nilotica . Journal of Zoology, 171 (1), 25-39. https://doi.org/10.1111/j.1469-7998.1973.tb07514.x

Naliato, R. F., Carvalho, P. L. P. F., Vicente, I. S. T., Xavier, W. d. S., Guimaraes, M. G., Rodrigues, E. J. D., . . . Orsi, R. d. O. (2021). Ginger (Zingiber officinale) powder improves growth performance and immune response but shows limited antioxidant capacity for Nile tilapia infected with Aeromonas hydrophila . Aquaculture Nutrition . https://doi.org/10.1111/anu.13229

Navarro, A., \& Martinez-Murcia, A. (2018). Phylogenetic analyses of the genus Aeromonas based on housekeeping gene sequencing and its influence on systematics. Journal of Applied Microbiology, 125 (3), 622-631. https://doi.org/10.1111/jam.13887

Naylor, R. L., Hardy, R. W., Buschmann, A. H., Bush, S. R., Cao, L., Klinger, D. H., . . . Troell, M. (2021). A 20-year retrospective review of global aquaculture. Nature, 591 (7851), 551-563. https://doi.org/10.1038/s41586-021-03308-6

Neamat-Allah, A. N., Mahmoud, E. A., \& Mahsoub, Y. (2021). Effects of dietary white mulberry leaves on hemato-biochemical alterations, immunosuppression and oxidative stress induced by Aeromonas hydrophila in Oreochromis niloticus. Fish 83 Shellfish Immunology, 108 , 147-156. https://doi.org/10.1016/j.fsi.2020.11.028

Nguyen, L.-T., Schmidt, H. A., Von Haeseler, A., \& Minh, B. Q. (2015). IQ-TREE: a fast and effective stochastic algorithm for estimating maximum-likelihood phylogenies. Molecular Biology and Evolution, 32 (1), 268-274. https://doi.org/10.1093/molbev/msu300

Patil, H. J., Benet-Perelberg, A., Naor, A., Smirnov, M., Ofek, T., Nasser, A., . . . Cytryn, E. (2016). Evidence of increased antibiotic resistance in phylogenetically-diverse Aeromonas isolates from semi-intensive fish ponds treated with antibiotics. Frontiers in Microbiology, 7, 1875. https://doi.org/10.3389/fmicb.2016.01875

Perez-Sanchez, T., Mora-Sanchez, B., \& Balcazar, J. L. (2018). Biological approaches for disease control in aquaculture: advantages, limitations and challenges. Trends in Microbiology, 26 (11), 896-903. https://doi.org/10.1016/j.tim.2018.05.002 
Peterman, M. A., \& Posadas, B. C. (2019). Direct economic impact of fish diseases on the East Mississippi catfish industry. North American Journal of Aquaculture, 81 (3), 222-229. https://doi.org/10.1002/naaq.10090

Pridgeon, J. W., \& Klesius, P. H. (2012). Major bacterial diseases in aquaculture and their vaccine development. CAB Reviews, 7 , 1-16. http://dx.doi.org/10.1079/PAVSNNR20127048

Ross, A., Ward, S., \& Hyman, P. (2016). More is better: selecting for broad host range bacteriophages. Frontiers in Microbiology, 7 , 1352. https://doi.org/10.3389/fmicb.2016.01352

Seemann, T. (2014). Prokka: rapid prokaryotic genome annotation.Bioinformatics, 30 (14), 2068-2069. https://doi.org/10.1093/bioinformatics/btu153

Seggel, A., \& De Young, C. (2016). Climate change implications for fisheries and aquaculture: summary of the findings of the Intergovernmental Panel on Climate Change Fifth Assessment Report.FAO Fisheries and Aquaculture Circular (C1122), I.

Stentiford, G., Bateman, I., Hinchliffe, S., Bass, D., Hartnell, R., Santos, E., . . . Verner-Jeffreys, D. (2020). Sustainable aquaculture through the One Health lens. Nature Food, 1 (8), 468-474. https://doi.org/10.1038/s43016-020-0127-5

Stentiford, G. D., Sritunyalucksana, K., Flegel, T. W., Williams, B. A., Withyachumnarnkul, B., Itsathitphaisarn, O., \& Bass, D. (2017). New paradigms to help solve the global aquaculture disease crisis.PLoS Pathogens, 13 (2), e1006160. https://doi.org/10.1371/journal.ppat.1006160

Stratev, D., \& Odeyemi, O. A. (2016). Antimicrobial resistance of Aeromonas hydrophila isolated from different food sources: A mini-review. Journal of Infection and Public Health, 9 (5), 535-544. https://doi.org/10.1016/j.jiph.2015.10.006

Tu, V. Q., Nguyen, T.-T., Tran, X. T., Millard, A. D., Phan, H. T., Le, N. P., . . . Hoang, H. A. (2020). Complete genome sequence of a novel lytic phage infecting Aeromonas hydrophila, an infectious agent in striped catfish (Pangasianodon hypophthalmus ). Archives of Virology, 165 (12), 2973-2977. https://doi.org/10.1007/s00705-020-04793-2

Turner, D., Reynolds, D., Seto, D., \& Mahadevan, P. (2013). CoreGenes3. 5: a webserver for the determination of core genes from sets of viral and small bacterial genomes. BMC Research Notes, 6 (1), 1-4. https://doi.org/10.1186/1756-0500-6-140

Van Twest, R., \& Kropinski, A. M. (2009). Bacteriophage enrichment from water and soil. In Bacteriophages (pp. 15-21): Springer.

Walker, J., Clokie, M., \& Kropinski, A. (2009). Bacteriophages: Methods and protocols, volume 1: Isolation, characterization, and interactions. In: Totowa, NJ: Humana Press.

Wang, J.-B., Lin, N.-T., Tseng, Y.-H., \& Weng, S.-F. (2016). Genomic characterization of the novel Aeromonas hydrophila phage Ahp1 suggests the derivation of a new subgroup from phiKMV-like family.PLoS One, 11 (9), e0162060. https://doi.org/10.1371/journal.pone.0162060

Wick, R. R., Judd, L. M., Gorrie, C. L., \& Holt, K. E. (2017). Unicycler: resolving bacterial genome assemblies from short and long sequencing reads. PLoS Computational Biology, 13 (6), e1005595. https://doi.org/10.1371/journal.pcbi.1005595

Zhang, D., Gao, F., Jakovlić, I., Zou, H., Zhang, J., Li, W. X., \& Wang, G. T. (2020). PhyloSuite: an integrated and scalable desktop platform for streamlined molecular sequence data management and evolutionary phylogenetics studies. Molecular Ecology Resources, 20 (1), 348-355. https://doi.org/10.1111/17550998.13096

\section{Tables and Figures}


Table 1. Bacterial strains used for determination of pAh6.2TG host range and specificity

\begin{tabular}{|c|c|c|c|c|c|c|}
\hline $\begin{array}{l}\text { Bacterial } \\
\text { species }\end{array}$ & Strain & Location & Source & Year & $\begin{array}{l}\text { pAh6.2TG } \\
\text { specific }\end{array}$ & References \\
\hline \multirow[t]{17}{*}{$\begin{array}{l}\text { A. } \\
\text { hydrophila }\end{array}$} & ВТ01 & $\begin{array}{l}\text { Ben Tre, } \\
\text { Vietnam }\end{array}$ & $\begin{array}{l}\text { Striped } \\
\text { catfish }\end{array}$ & 2018 & - & $\begin{array}{l}\text { Laboratory } \\
\text { strain }\end{array}$ \\
\hline & ВТ02 & $\begin{array}{l}\text { Ben Tre, } \\
\text { Vietnam }\end{array}$ & $\begin{array}{l}\text { Striped } \\
\text { catfish }\end{array}$ & 2018 & - & $\begin{array}{l}\text { Laboratory } \\
\text { strain }\end{array}$ \\
\hline & ВТ03 & $\begin{array}{l}\text { Ben Tre, } \\
\text { Vietnam }\end{array}$ & $\begin{array}{l}\text { Striped } \\
\text { catfish }\end{array}$ & 2018 & + & $\begin{array}{l}\text { Laboratory } \\
\text { strain }\end{array}$ \\
\hline & ВТ04 & $\begin{array}{l}\text { Ben Tre, } \\
\text { Vietnam }\end{array}$ & $\begin{array}{l}\text { Striped } \\
\text { catfish }\end{array}$ & 2018 & + & $\begin{array}{l}\text { Laboratory } \\
\text { strain }\end{array}$ \\
\hline & ВТ05 & $\begin{array}{l}\text { Ben Tre, } \\
\text { Vietnam }\end{array}$ & $\begin{array}{l}\text { Striped } \\
\text { catfish }\end{array}$ & 2018 & + & $\begin{array}{l}\text { Laboratory } \\
\text { strain }\end{array}$ \\
\hline & BT12 & $\begin{array}{l}\text { Ben Tre, } \\
\text { Vietnam }\end{array}$ & $\begin{array}{l}\text { Striped } \\
\text { catfish }\end{array}$ & 2018 & + & $\begin{array}{l}\text { Laboratory } \\
\text { strain }\end{array}$ \\
\hline & $\mathrm{BT} 9^{+}$ & $\begin{array}{l}\text { Ben Tre, } \\
\text { Vietnam }\end{array}$ & $\begin{array}{l}\text { Striped } \\
\text { catfish }\end{array}$ & 2018 & + & $\begin{array}{l}\text { Laboratory } \\
\text { strain }\end{array}$ \\
\hline & BT13 & $\begin{array}{l}\text { Ben Tre, } \\
\text { Vietnam }\end{array}$ & $\begin{array}{l}\text { Striped } \\
\text { catfish }\end{array}$ & 2018 & + & $\begin{array}{l}\text { Laboratory } \\
\text { strain }\end{array}$ \\
\hline & BT14 \# & $\begin{array}{l}\text { Ben Tre, } \\
\text { Vietnam }\end{array}$ & $\begin{array}{l}\text { Striped } \\
\text { catfish }\end{array}$ & 2018 & + & $\begin{array}{l}\text { Dien et al. } \\
(2021)\end{array}$ \\
\hline & BT22 & $\begin{array}{l}\text { Ben Tre, } \\
\text { Vietnam }\end{array}$ & $\begin{array}{l}\text { Striped } \\
\text { catfish }\end{array}$ & 2018 & + & $\begin{array}{l}\text { Laboratory } \\
\text { strain }\end{array}$ \\
\hline & TG26 & $\begin{array}{l}\text { Tien Giang, } \\
\text { Vietnam }\end{array}$ & $\begin{array}{l}\text { Striped } \\
\text { catfish }\end{array}$ & 2018 & + & $\begin{array}{l}\text { Laboratory } \\
\text { strain }\end{array}$ \\
\hline & TG35 & $\begin{array}{l}\text { Tien Giang, } \\
\text { Vietnam }\end{array}$ & $\begin{array}{l}\text { Striped } \\
\text { catfish }\end{array}$ & 2018 & + & $\begin{array}{l}\text { Laboratory } \\
\text { strain }\end{array}$ \\
\hline & CUVET02 & $\begin{array}{l}\text { Chonburi, } \\
\text { Thailand }\end{array}$ & $\begin{array}{l}\text { Asian } \\
\text { seabass }\end{array}$ & 2020 & - & $\begin{array}{l}\text { Laboratory } \\
\text { strain }\end{array}$ \\
\hline & CUVET21 & $\begin{array}{l}\text { Chonburi, } \\
\text { Thailand }\end{array}$ & $\begin{array}{l}\text { Walking } \\
\text { catfish }\end{array}$ & 2020 & - & $\begin{array}{l}\text { Laboratory } \\
\text { strain }\end{array}$ \\
\hline & CUVET46 & $\begin{array}{l}\text { Kanchanaburi, } \\
\text { Thailand }\end{array}$ & Nile tilapia & 2020 & - & $\begin{array}{l}\text { Laboratory } \\
\text { strain }\end{array}$ \\
\hline & CUVET52 & $\begin{array}{l}\text { Uttaradit, } \\
\text { Thailand }\end{array}$ & Nile tilapia & 2020 & - & $\begin{array}{l}\text { Laboratory } \\
\text { strain }\end{array}$ \\
\hline & CUVET92 & $\begin{array}{l}\text { Kanchanaburi, } \\
\text { Thailand }\end{array}$ & Nile tilapia & 2020 & - & $\begin{array}{l}\text { Laboratory } \\
\text { strain }\end{array}$ \\
\hline \multirow[t]{3}{*}{ A. veronii } & NK01 & $\begin{array}{l}\text { Nongkhai, } \\
\text { Thailand }\end{array}$ & Nile tilapia & 2014 & - & $\begin{array}{l}\text { Dong et al. } \\
(2015 \mathrm{a})\end{array}$ \\
\hline & NK02 & $\begin{array}{l}\text { Nongkhai, } \\
\text { Thailand }\end{array}$ & Nile tilapia & 2014 & - & $\begin{array}{l}\text { Dong et al. } \\
(2015 a)\end{array}$ \\
\hline & NT03 & $\begin{array}{l}\text { Pathum } \\
\text { Thani, } \\
\text { Thailand }\end{array}$ & Nile tilapia & 2016 & & $\begin{array}{l}\text { Dong et al. } \\
\text { (2017) }\end{array}$ \\
\hline \multirow[t]{3}{*}{ A. schubertii } & N1 & $\begin{array}{l}\text { Tra Vinh, } \\
\text { Vietnam }\end{array}$ & $\begin{array}{l}\text { Snakehead } \\
\text { fish }\end{array}$ & 2016 & - & $\begin{array}{l}\text { Laboratory } \\
\text { strain }\end{array}$ \\
\hline & N3 & $\begin{array}{l}\text { An Giang, } \\
\text { Vietnam }\end{array}$ & $\begin{array}{l}\text { Snakehead } \\
\text { fish }\end{array}$ & 2016 & - & $\begin{array}{l}\text { Laboratory } \\
\text { strain }\end{array}$ \\
\hline & N7 & $\begin{array}{l}\text { Dong Thap, } \\
\text { Vietnam }\end{array}$ & $\begin{array}{l}\text { Snakehead } \\
\text { fish }\end{array}$ & 2016 & - & $\begin{array}{l}\text { Laboratory } \\
\text { strain }\end{array}$ \\
\hline
\end{tabular}




\begin{tabular}{|c|c|c|c|c|c|c|}
\hline E. ictaluri & T1-1 & $\begin{array}{l}\text { Ratchaburi, } \\
\text { Thailand }\end{array}$ & $\begin{array}{l}\text { Striped } \\
\text { catfish }\end{array}$ & 2014 & - & $\begin{array}{l}\text { Dong et al. } \\
\text { (2015b) }\end{array}$ \\
\hline S. agalactiae & 2809 & Thailand & Nile tilapia & 2018 & - & $\begin{array}{l}\text { Jhunkeaw et } \\
\text { al. }(2021)\end{array}$ \\
\hline & VTCC & Vietnam & Pickles & 2009 & - & Vietnam \\
\hline fermentum & 11051 & & & & & Type \\
\hline & & & & & & $\begin{array}{l}\text { Culture } \\
\text { Collection }\end{array}$ \\
\hline & VTCC & Vietnam & Pickles & 2009 & - & Vietnam \\
\hline plantarum & 10890 & & & & & Type \\
\hline & & & & & & Culture \\
\hline & & & & & & Collection \\
\hline
\end{tabular}

+MDR strain used in in vitro assays, \#MDR strain used in challenge test.
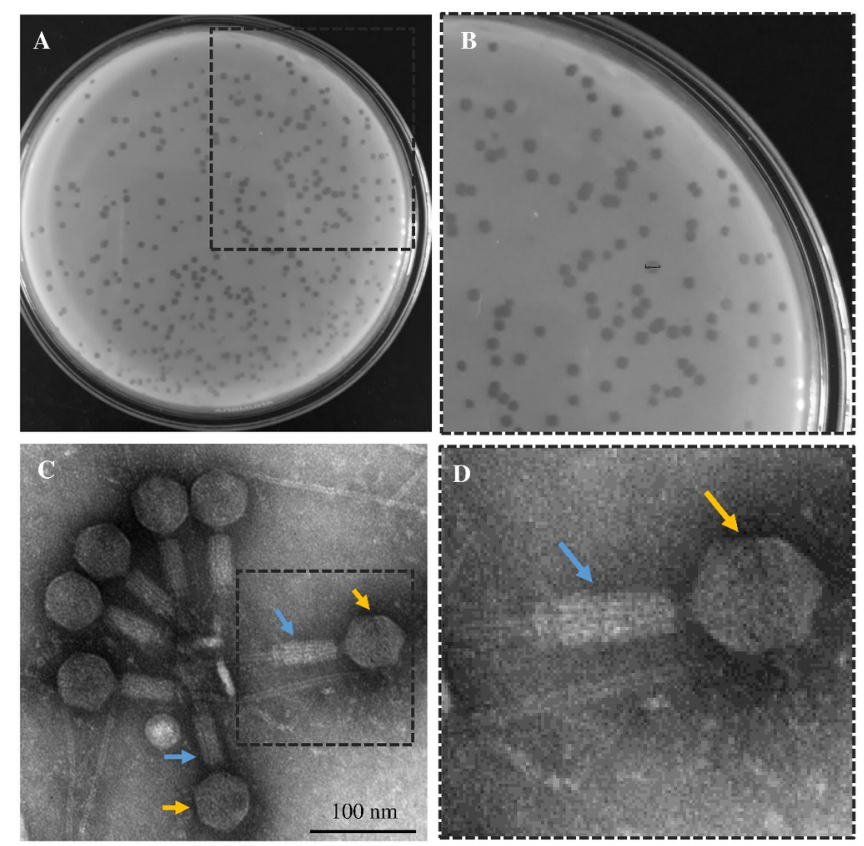

$\Rightarrow$ icosahedral head

$\rightarrow$ contractile tail

Figure 1. (A \& B) Plaques of pAh6.2TG on double layer TSA. (C \& D) Transmission electron micrographs of pAh6.2TG. 

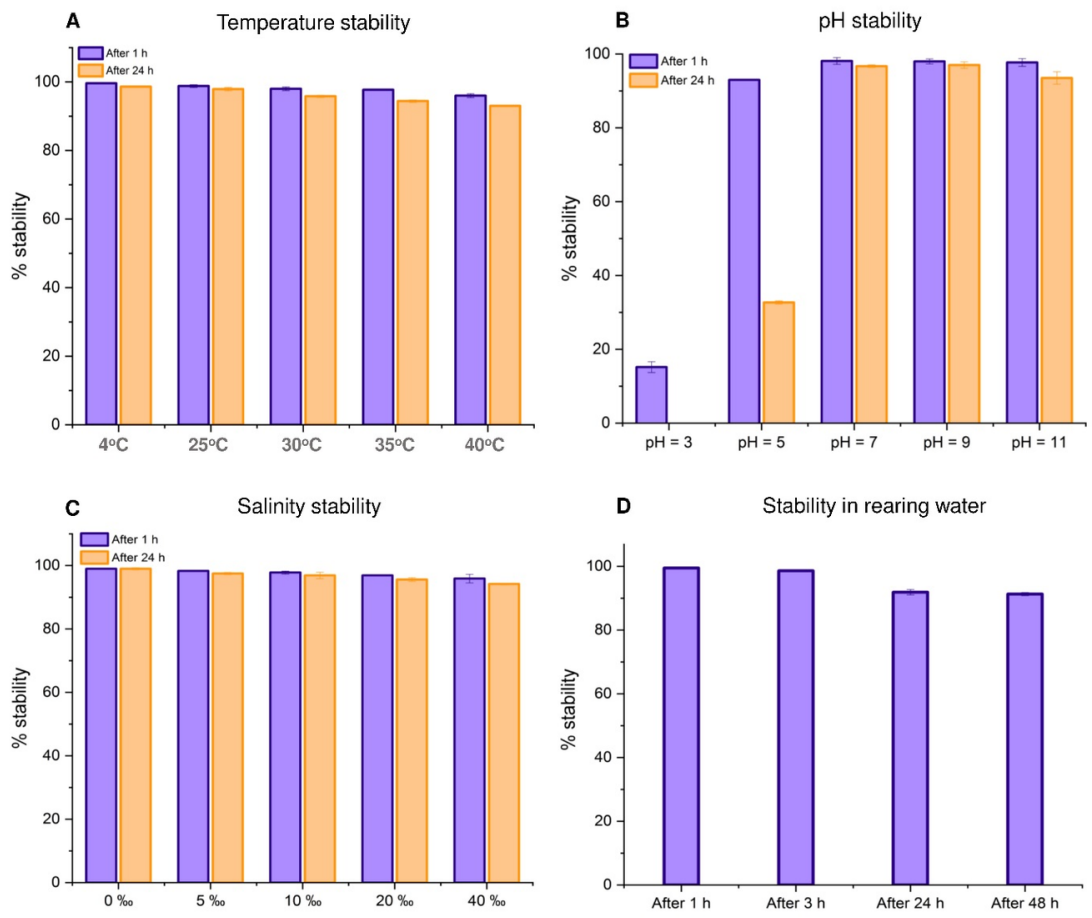

Figure 2. Stability of phage pAh6.2TG. (A) Temperature stability. (B) pH stability. (C) Salinity stability. (D) Stability in rearing water. Value of $\%$ stability are mean \pm a standard error of the mean (SEM) bar (n $=3$ in Figure A, B, C and $\mathrm{n}=2$ in Figure D).

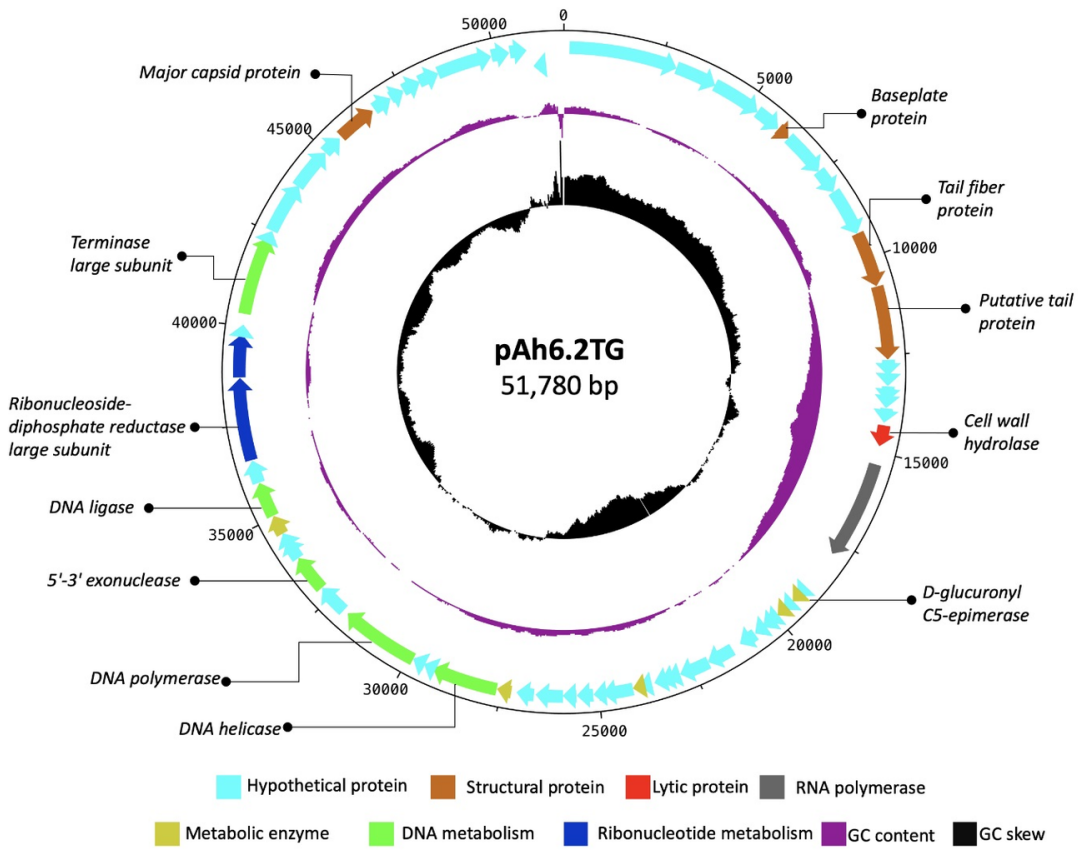


Figure 3. Genome map of phage pAh6.2TG. Arrows represent the annotated ORFs which are shown in various colors indicating their predicted protein function. Two inner rings represent the GC skew (in black) and GC content (in violet). Some genes of interest are marked.
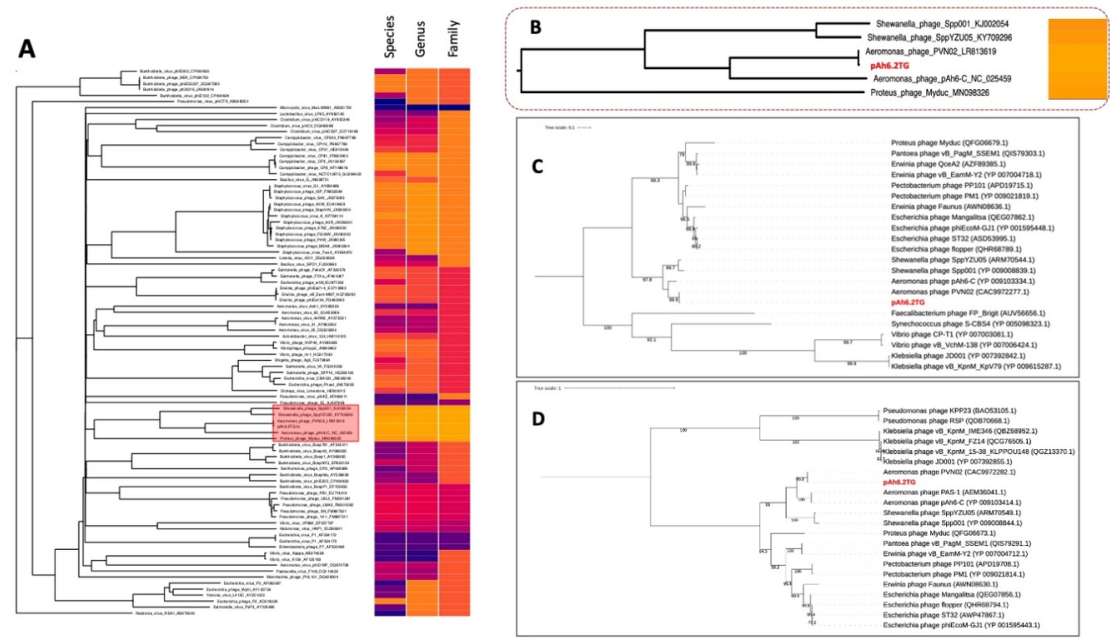

Figure 4. Phylogenetic analyses based on (A and B) whole genome, $(\mathrm{C})$ major capsid protein sequence, and (D) terminase large subunit. (A) Comparative genomics $(n=91)$ was performed using VICTOR web server with settings recommended for prokaryotic viruses. Clustering of viruses at species, genus, and family level was determined automatically and allocated by color strips adjacent to the phylogenomic tree (same color representing identical taxonomic unit). Red box indicates phage pAh6.2TG and its monophyletic taxa which is magnified in panel B. Trees based on (C) major capsid protein and (D) terminase large subunit were constructed by the maximum-likelihood method with 5,000 ultrafast bootstrapping. Bootstrap value (in percentage) is shown at the node, whereas scale bar indicates amino acid substitution per site. Red taxon represents the phage of this study (pAh6.2TG). 


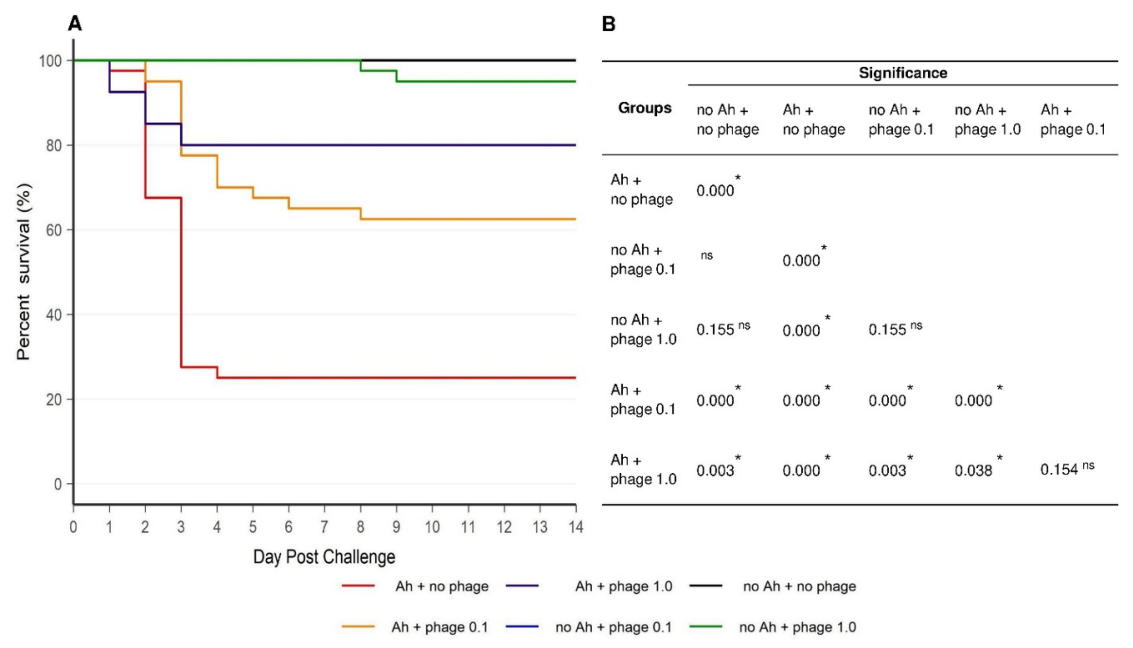

Figure 5. Kaplan - Meier analysis of percentage survival of Nile tilapia $(\mathrm{n}=40)$ challenged with MDR $A$. hydrophila BT14 (A). Differences between groups were tested using log-rank test (B). "*" denotes significant difference $(p<0.05)$, and "ns" means not significant.
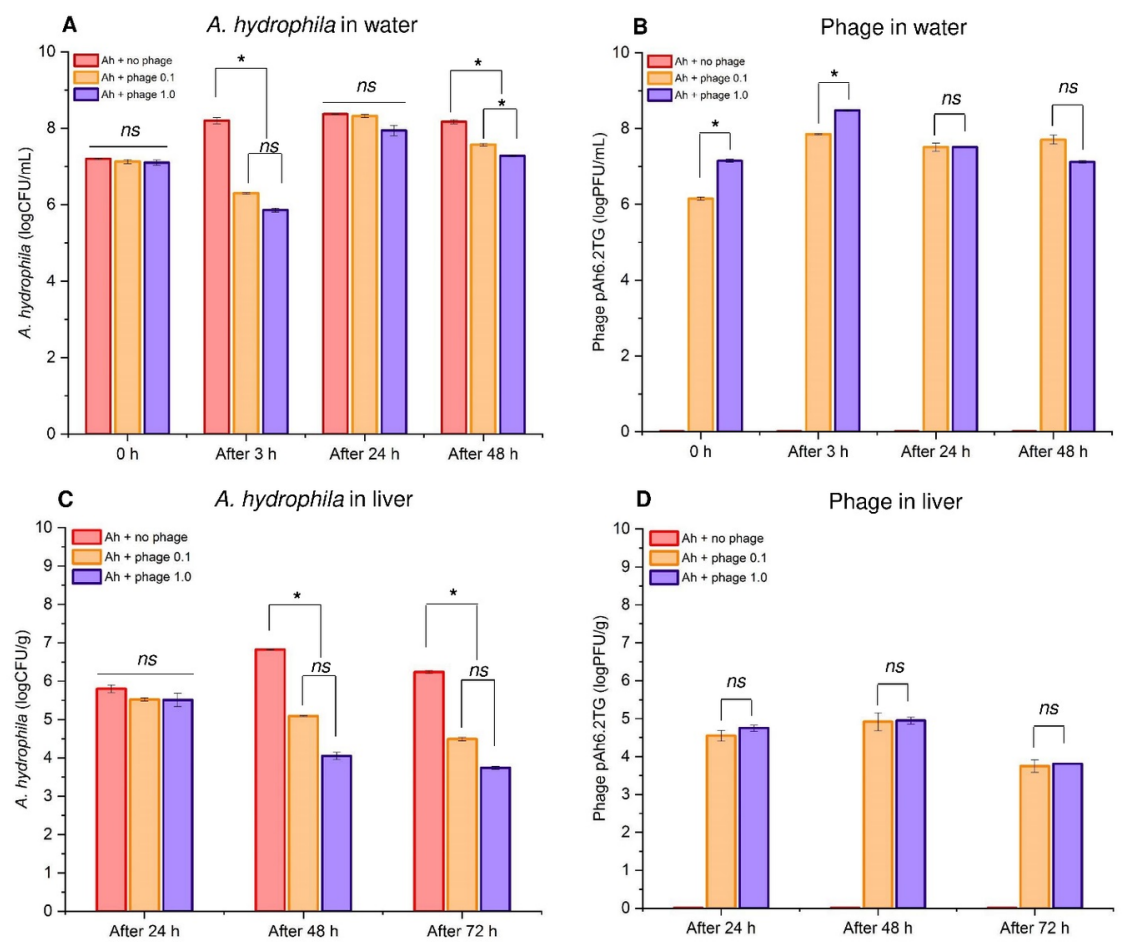
Figure 6. Enumeration of $A$. hydrophila concentration and phage titer in rearing water and fish liver samples. (A) A. hydrophila concentration in rearing water $(\log \mathrm{CFU} / \mathrm{mL})$. (B) Phage pAh6.2TG titer in rearing water $(\log \mathrm{PFU} / \mathrm{mL})$. (C) A. hydrophilaconcentration in fish liver $(\log \mathrm{CFU} / \mathrm{g})$. (D) Phage pAh6.2TG titer in fish liver $(\log \mathrm{PFU} / \mathrm{g})$. Value of $A$. hydrophila concentration and phage titer are mean \pm a standard error of the mean (SEM) bar $(\mathrm{n}=2)$ and "*" above the bar indicates significant difference between groups $(p<0.05)$, " $n s "$ means not significant.

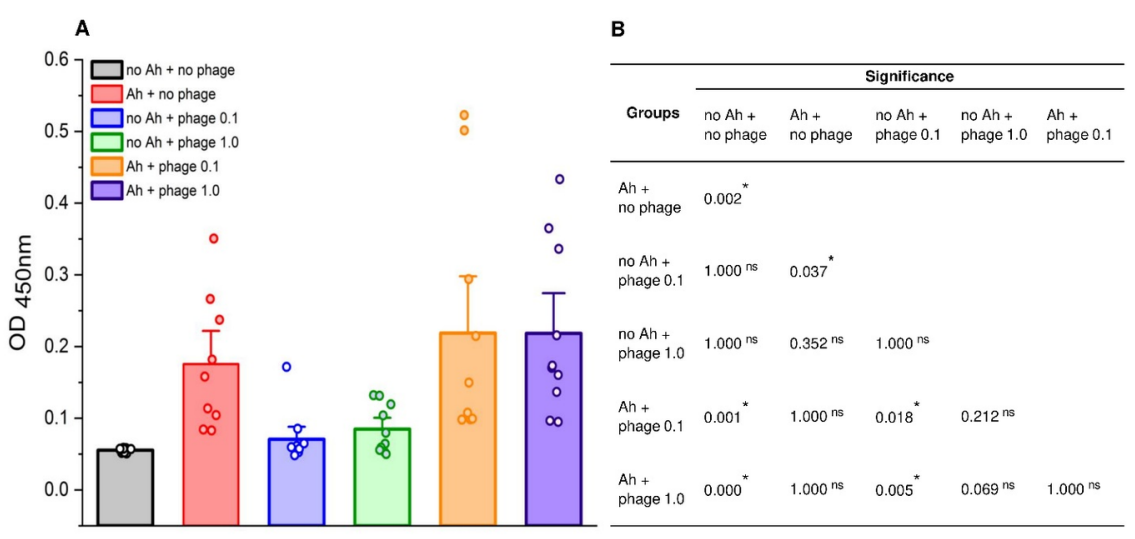

Figure 7. Indirect ELISA analysis of A. hydrophilaspecific IgM antibody. Fish sera were collected on day 14 and dilutions with 1:256 were used to test for antigen specific IgM. Data were expressed as mean absorbance at $\mathrm{OD}_{450 \mathrm{~nm}}$ with a SEM bar (A). One dot represents one biological replicate $(\mathrm{n}=9$ in group $\mathrm{Ah}+$ no phage, $\mathrm{n}=10$ in other groups). Differences between groups were tested using log-rank test (B). "** denotes significant difference $(p<0.05)$, and "ns" means not significant. 